\title{
A list of published papers is no measure of value
}

The present system rewards quantity, not quality - but hasty changes could be as bad.

Sir - The choice of performance indicators sends a powerful message to those being evaluated, and when those measures are linked to the distribution of research funds, academics are quick to respond. Our analysis of Australian university publications shows clearly how the sector has reacted to funding formulae that reward quantity rather than quality.

A large part of thegovernment funds that support the research activities of Australian universities is allocated on the basis of formulaethat comprise three elements: research income, postgraduate students and publications ${ }^{1}$. Data on the third element have been collected annually since 1993. When thiselement was incorporated into the funding formulae in 1995, universities and researchers were quick to calculate the 'value' of a publication.

Between 1995 and 2000, thisfigure varied from $A \$ 761$ (US\$415) to $A \$ 1,089$, influenced by the publication types included and thetotal funds allocated. After a review of higher-education research in 1999, the amount to be distributed via formulae increased significantly, to more than half of the funding specifically targeted to research and research training through the Education, Science and Training portfolio. As a result, a published paper is now 'worth' more than $A \$ 3,000$ to a university. The value to individuals or departments can beappreciably higher. ${ }^{2}$ Some universities distribute these funds internally using the same formula, but giving more weight to publications - up to three times the sector value.

We have quantified the apparent effect of this policy. We have distributed all journals from the Institute for Scientific Information's (ISI) Science Citation Index (SCI) into quartiles, using journal impacts calculated on the basis of five-year citation means, and have tracked the presence of Australian universities in thesefour journal sets over time (Figure1).

The response of theacademic community was predictableand clear. Until the 1989-93 period, therehad been virtually no movement in theinstitutions' presence in the $\mathrm{SCl}$ journal sets. Subsequently, university output jumped noticeably, even though funds remain extremely tight and academic staff numbers stable. The most striking feature of that increase has been itslack of uniformity. The sector's share of publications in the top two quartiles rose by around $20 \%$, but in thethird quartile

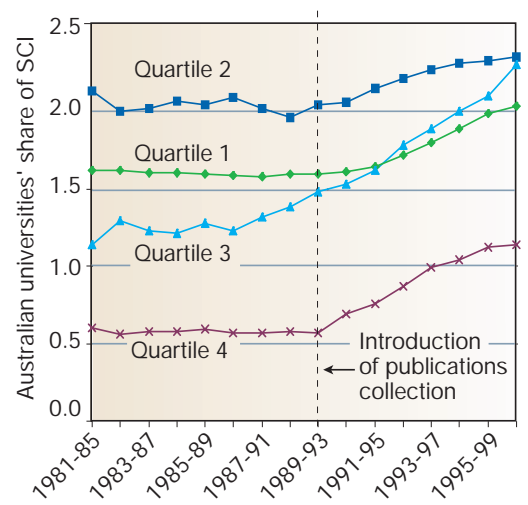

Figure 1 Australian universities' share of publications in the $\mathrm{SCl}$, by journal impact quartile: five-year windows, 1981-1985 to 1996-2000.

its share increased by over $50 \%$, and it doubled in the bottom quartile.

With no differentiation between the quality or impact of the publications, thereis littleincentiveto strivefor placement in a prestigiousjournal. Whether a publication is a groundbreaking piecein Nature, or a pedestrian piece in a low-impact journal, the rewards are identical. And with therecent trebling in the 'value' of a publication unit, the

\section{Realistic attitude takes postdocs a long way}

Sir - Compared with other countries in Asia, Japan is often described in discouraging terms with respect to foreign researchersworking there (see, for example, Naturejobs 4- 5, 8 August 2002). I havejust completed four years' postdoctoral work in Japan, and agreethat it ismore difficult for Japan than for the United States or Europeto attract young foreign researchers. This is a great pity, as both the country and its science havea lot to offer postdoctoral fellows.

One of the greatest obstacles is the image that Western scientists have of Japan. At a recent conference, numerous graduatestudents and postdocs asked me questions about my experience, almost al ways starting out with whether it is difficult to livethere. $\mathrm{No}$, it is not difficult - not least because the financial support provided by institutions such as the Japan Society for the Promotion of Science (JSPS) is very generous.

Two critical elements for a successful stay arethe attitudes of the researcher and pressureto focus on this will not diminish.

Concerns that this component of the funding formula was not measuring the characteristic that it was designed for quality - were raised soon after its introduction. However, not all universities were keen to see it removed or replaced. For smaller institutions, this particular element was more rewarding, and easier to improve, than the others.

These concerns are now re-surfacing in the context of the latest review of the Australian higher education system ${ }^{3}$. A number of submissions to recent ministerial discussion papers have suggested theremoval or modification of the publications component. The difficulty is that suggested alternatives are as problematic as the one they seek to replace. It is to be hoped that time will be taken to analysethelikely effects of any alternativemeasures before they are introduced.

\section{Linda Butler}

Research Evaluation and Policy Project, Research School of Social Sciences, TheAustralian National University, ACT 0200, Australia

\footnotetext{
1. http://www.detya.gov.au/highered/research/index.htm

2. http://www.avcc.edu.au/policies_activities/resource_analysis/ key_stats/kstats.htm

3. http://www.detya.gov.au/crossroads
}

of the laboratory head. Foreign researchers should develop at least basic Japanese language skills and not expect thelab to burst into English for every detail. Although good speakers may cometo the institution, Japan is geographically distant from countries in which most scientific meetings are held, so visiting postdocs should make the most of the grants offered by the JSPS for travel to conferences.

The wonderful timel experienced in Japan waslargely due to the supportive nature of thelab I worked in. Frequently, however, one hears stories wherethis is not the case. If the sensei (lab head) is unenthusiastic or is prejudiced against foreign researchers, conflicts arise. In my view, it is crucial for a researcher to meet his or her prospective lab head before deciding to move.

AsPhD graduates rarely have the funds to travel at theend of their studies, a programme (perhapsfunded byJSPS) to allow a visit to a prospective lab, with no commitment on either side, would be useful in establishing regular successful working relationships between foreign and Japaneseresearchers. Preparedness and 
flexibility arethekey to finding success and happiness whileworking in Japan.

\section{StuartFraser}

Laboratory of M olecular M ouse Genetics, Institutefor Toxicology, Johannes GutenbergUniversity M ainz, O bereZahlbacher Strasse 67 , Mainz 55131, Germany

\section{Science, conservation and fox-hunting}

Sir - Much evidence on theissue of foxhunting with hounds is either speculative, being based on questionnaire surveys, or contradictory, particularly wherefundsare provided by special-interest groups. The recent study done at Bristol University (P. J. Baker, S. Harris\& C. J. Webbon, Nature 419, 34; 2002) is noteworthy for attempting an experimental approach.

Baker et al. found that thetemporary cessation of fox-hunting in Britain during the foot-and-mouth disease outbreak of 2001 had no impact on fox population density, and concluded that a permanent ban on hunting is unlikely to result in a dramatic increase in fox numbers. H owever, motor vehicles are the greatest killer of foxesin Britain, accounting for some $25 \%$ of deaths. Hunting with hounds accounts for only $6.3 \%$ of the 400,000 foxes killed annually. M orethan fivetimesas many are killed by shooting and snaring as by hunting with hounds in lowland hunting areas (L. Burns, V. Edwards, J. M arsh, L. Soulsby \& M. Winter. Report of the Committee of Inquiry into H unting with D ogsin England and Wales, Stationery Office, London; 2000; see www.huntinginquiry.gov.uk). Fox-hunting isan ineffectivemethod of population control .

Instead, these data suggest that foxhunting harvests a sustainable off-take, which might represent a traditional form of community-based conservation. Such projects improve local tolerancetowards wildlifeand maintain biodiversity without statutory regulation and recurrent public funding. The British government has supported many such projects in developing countries, and is committed to doing the samein Britain as a signatory to the Convention on Biological Diversity.

The defence of fox-hunting on conservation grounds relies on two main predictionsin theevent of a ban: first, that voluntary maintenance of biodiversityrich fox habitats such as woodlands and hedgerows by landowners involved in hunting would decline; second, that landowners' tolerance of foxes would decline, increasing their persecution by other potentially less humanemethods and so reducing fox numbers. Landowners may havethepotential to reduce fox densities by shooting and snaring (M. Heydon \& J. Reynolds, J. Zool. 251, 265; 2000), but using these results to predict changes after any ban remains problematic.

The best way to test these predictions would be to build on theopportunistic approach attempted by Baker et al. by imposing a temporary, medium-term ban in randomly chosen areas and conducting independently funded research into its effects on a range of factors. This adaptive management approach would satisfy Lord Burns's recent recommendation not to rush a decision on whether to ban hunting. Although this approach hasits pitfalls, we believe that, with careful planning, it would provide a firmer scientific basisfor legislation than existing evidence.

N. Leader-Williams, T. E. E. Oldfield, R. J. Smith \& M. J. Walpole Durrell Institute of Conservation and Ecology, University of Kent at Canterbury, Canterbury CT2 7NS, Kent, UK

\section{Culture gap: in biology, what works, continues}

Sir - Despitetheargumentsreported in your News Feature"Bridging the culture gap" (Nature 419, 244-245; 2002), biologists already havea simpleunifying rule, without thehelp of physicists. It is 'what works, continues' - usually stated in terms of thesurvival and reproduction of the fittest.

In answer to a posed question: phosphate is used to activate and deactivate proteins, as are methyl and ethyl groups and various saccharides, for the same reason that I currently usegreen and orange highlighters. At some timein the past they were there and functioned, and were incorporated into the system. Applied mathshasits place in biology, especially wheresimplerules apply, in detecting signal in noise and defining practical limits.

M endel was the first and most influential in this regard. Hiswork was so clever, or so arcane, that it took 35 years to work out what he had discovered, and another 50 years for molecular genetics to explain the mechanism that causes dominance. Typically, Mendel's laws underestimate reality. The effects of most alleles on most characters are quantitative, polygenic and multi-factorial, rather than qualitative - tall versusshort.

Comparean organism to an automated factory. Physics can explain all of the functions from electronsin transistors to computers in robots to metal-forming stresses and welding, but it hastroublewith company balance sheets and share prices.
In business, the overriding factor is market share; in biology, habitat occupation.

\section{Hugh Fletcher}

School of Biology and Biochemistry, Queen's University of Belfast, 97 Lisburn Road, Belfast BT 9 7BL, UK

\section{Culture gap: physics still seeks its unifying theory}

Sir - I was somewhat bemused when reading your News Feature (Nature419, 244-246; 2002). The view that "biology today is where physics was at the beginning of thetwentieth century" misses a critical differencebetween the two disciplines. Biology has a grand unifying theory: it was published in 1859 by CharlesD arwin as $\mathrm{O} n$ the O rigin of Species by M eans of $\mathrm{N}$ atural Selection. Thesamecannot besaid of physics, which continues to search for its theory of everything.

\section{J. Hosken}

Zoology M useum, University of Zurich, Winterthurerstr 190, 8057 Zurich, Switzerland

\section{Patents limit medical potential of sequencing}

Sir - In your interesting Nature Science U pdate1 "24-hour genomedawns", you report on the prospect of a personal sequencein minutes, for less than $\$ 1,000$. Patents will present at least two major problems to thetimely adoption of these technologies ${ }^{2,3}$.

First, someU S companies will not license 'their' genes for testing by others, so any diagnostic chip would have to skip the patented gene estate of M yriad Genetics and similar outfits. Second, for those willing to license their genes nonexclusively for inclusion in diagnostic gene chipsand similar tools, the stacked royalties payableon all the patented genes will make thetests prohibitively expensive.

Technological advances will benefit patients only if owners of diagnostic gene patents permit the technologies to be used and are reasonablein their demands for royalties, such as by limiting their expectationsto a small fraction, say $1-3 \%$, of the marginal cost allocable to their genes ${ }^{4}$.

\section{Jon F. Merz}

Center for Bioethics, University of Pennsylvania, 3401 M arket Street, Suite 320, Philadel phia, Pennsylvania 19104-3308, USA

\footnotetext{
1. http://www.nature.com/nsu/020923/020923-2.html; 24 September 2002

2. Schissel, A., M erz, J. F. \& Cho, M. K. Nature 402, 118 (1999).

3. Merz, J. F., Kriss, A. G., Leonard, D. G. B. \& Cho, M. K. Nature 415, 577-579 (2002).

4. Merz, J. F. Clin. Chem. 45, 324-330 (1999).
} 